\title{
Evaluating the Nature and Challenges to Pastoral Care in Catholic Sponsored Schools in Nakuru Municipality, Nakuru County, Kenya
}

\author{
Victoria Nduku ${ }^{1}$, Boaz Onyancha ${ }^{1}$, Joshua Ayiemba ${ }^{1}$ \\ ${ }^{1}$ Egerton, Unversity Njoro, Kenya \\ Correspondence: Victoria Nduku, Egerton, Unversity, Njoro, Kenya. \\ Received: July 31, 2016 \\ Accepted: August 12, 2016 \\ Available online: November 9, 2016 \\ doi:10.11114/ijsss.v4i12.1973 \\ URL: http://dx.doi.org/10.11114/ijsss.v4i12.1973
}

\begin{abstract}
Catholic Church sponsored schools have generally exhibited great academic performance all over Kenya. However, there are a number of challenges facing these Schools which have not been studied and documented. The purpose of this paper is therefore to share the findings of the Nature and Pastoral Care challenges facing Catholic Church- sponsored schools in Nakuru Municipality in Nakuru County. The objectives of the paper are; to establish the nature of Pastoral Care in Catholic Church-sponsored schools in Nakuru Municipality and to assess the challenges to proper Pastoral Care in Catholic managed schools in the Nakuru Municipality. The paper is justified by a lack of existing literature on the challenges facing these schools. The paper is guided by the theory of abundant life attributed to Jesus Christ and deprivation theory propounded by John Bowlby (2007). Th is paper uses qualitative research method incorporating interviews, questionnaires and focus group discussions to collect data. A sampled population of 216 including teachers, prefects, principals and a group of students for focused group discussions are selected purposively for this paper. The data collected is analyzed descriptively. The findings and recommendations of this paper are hopefully helpful to the policy makers oneducation both state and non-state actors.
\end{abstract}

Keywords: pastoral care, challenge, Catholic church

\section{Introduction}

\subsection{The Problem}

The Catholic sponsored schools are generally perceived to be the best by the Kenyan public. For example in the 2007 Kenya Certificate of Secondary Education results, the Catholic church - sponsored schools which led were Mang'u High School, first position, Precious Blood, Riruta, third position, Loreto Girls, Limuru fourth position, Nairobi,school,sixth position and Strathmore School, seventh position. (en.wikipedia.org/wiki/Mang'u_High_School Wikipedia). The spons orship of schools by religious institutions has origins in the missionary period. At independence in the 1960's, the state recognized the church as a development partner and therefore the Church-state relationships and cooperation is cordial in matters of development. This cooperation is in accordance with the African traditional motto; "Harambee. The cooperation has been particularly evident in the fields of education, medicine and social work in which it has taken various forms. The church-state relationship began during the colonial period and has continued since independence to date. Cooperation between the church and the state especially on matters of education was encouraged and given a new impetus by Kenya's first president, Mzee Jomo Kenyatta, when in 1964 he called upon the people of Kenya and other residents, irrespective of race, religion or origin, to join hands to build the new nation. (Kenyatta, 1965).

\subsection{Importance of the Problem}

In spite of this good public image among Catholic Church-sponsored schools, there is clear evidence of some Pastoral Care challenges. There has been the problem of students' gross disobedience to school rules leading to moral decadence in the schools. Another challenge experienced by schools is over-emphasis by teachers to complete the syllabus thereby overlooking the opportunities for pastoral care programme that enhance character formation. Abuse of drugs such as alcohol by students is also another challenge in many Catholic sponsored schools. Alcohol intake by students is related to student misconduct in schools, which has become a major challenge to school administration. Teenage intimate relationship is also another major challenge in these schools. This has brought about early pregnancies that have resulted to early marriages and abortions. However, these challenges have not been a subject of any systematic investigation and documentation, which is the focus of this paper. 


\subsection{Relevant Scholarship}

\subsubsection{Nature of Pastoral Care}

Pattison (1993) primarily addresses the practicing pastors and students in training on courses for pastoral ministry. He discusses the ultimate aims and ends of pastoral care, the values and behavior patterns that pastoral care encourages. In addition, he describes the discipline required of those who are pastoral care givers and especially the spiritual. Pattison further argues that discipline cannot be separated from discip leship. Drawing on psychological, theological, and cultural studies on suffering, Doehring (2006) and Adams, (1970) encouraged counselors to view their ministry through trifocal lenses which include pre-modern (apprehending God through religious rituals), modern (consulting rational and empirical sources), and postmodern (acknowledging the contextual nature of knowledge approaches. For example, Doehring(2006) describes the basic ingredients of a care giving relationship, showed how to use the caregiver's life experience as a source of authority, and demonstrates how to develop the skills of listening and establishing the actual relationship. Patton (2005) and Den is (2006) have emphasized the essentials of Pastoral Care which involve the pastor's distinctive task of caring for those who are estranged--the lost sheep. Taken from the biblical image of the shepherd, the pastor by virtue of his or her professional calling cultivates wise judgment in order to hear the hurting and offer guidance, reconciliation, healing, sustaining presence, and empowerment to those in need. The book outlines the quintessential elements pastors need to wisely minister in today's context by discussing four major kinds of looseness: grief, illness, abuse, and family challenges. Augsburger (1995) discusses the dynamics of Pastoral Care and counseling along cultural lines. Augsburger (1995) views theology from global perspective and cultural sensitivity to posit an inclusive understanding of Pastoral Care.

The relationship between the pastor and parishioner is the essence of pastoral counseling --a simple truth with profound implications. Day ringer (1998) explores these implications to help pastoral counselors understand how to use the relationship to 4 bring about the desired ends in the therapeutic process. Dra wing on research from the disciplines of psychiatry, psychology, marriage counseling, family therapy, and pastoral counseling, Day ringer's book had foundation for utilizing the pastoral counseling relationship to bring about positive change as it explored topics such as observation, listening, communication, handling transference, and termination of therapy. On the other hand, Stone (1993) and Berg (1989) put emphasis on ministers-both the clergy and lay-who are often the first recourse for people in cris is, and people expect them to navigate through emergency, tragedy, disaster and loss. Often these persons were paraly zed and they expected help to get in motion again. Crisis counseling is relevant for persons who sought to provide such assistance, whether as ministers or hotline volunteers or pastoral counselors. According to Floyd (2008) and Edward (2004) "crisis counseling" represents a much-needed resource for the professional, pastoral, and even lay counselors. Their work provides biblically based framework for responding to crisis events in times of trau ma, loss and grief. The book offer specific examples from the Scripture and everyday life. It also treats specialized areas of crisis counseling, including how to work with children and teenagers in crisis circumstances and how to develop a crisis response team in a church setting. The work helps reader's deal with the stress, burn out, and secondary trauma that often accompany crisis ministry and counseling. On the other hand, Lester (1995) demonstrates that pastoral theology as well as social and behavioral sciences has effectively addressed the predominant cause of human suffering: a lack of hope, a sense of futureless. He further asserted that pastoral theology and other social and behavioral sciences have overlooked the importance of hope and despair in the past. Lester thus offered the starting points for addressing these significant dimensions of human life.

\subsubsection{Challenges to Pastoral Care}

Gerkin(1994),Mclemorie and Neuger (2004) have discussed the predominance of the psychotherapeutic paradigm in Pastoral Care which he viewed as a dynamic, interactive process which balances faith, culture, community, and individual well-being. Gerkin's history of pastoral care was skilfully written and his analysis of the current transitions in the field of care made this book a classic piece relevant for the current study. Gerkin's main approach is however, on dynamic interactive process. Grossoehme (1993) and Clinebell (1984) explore a new way of pastoral care that enables caregivers to develop relationships and provide meaningful pastoral care to the children and youth they encounter. The pastoral care of children focuses on the need for pastoral caregivers, clergy and chaplains to develop relationships with youths and gives suggestions to overcome the an xiety associated with caring for an acutely ill child through unique, playful, and child-cantered approaches. The pastoral care of children is a resourceful book that will assist one in overcoming an xiety and help one deliver thoughtful and uplifting pastoral care to child ren and youth. Ramsay (1998) has done a lengthy analysis of pastoral assessment of parishioners' problems. The book discusses the theological and ethical foundations of the Judeo-Christian tradition for pastoral care. It opens up lines of communication between pastoral theology and the other theological disciplines. 


\subsection{Corresponding Theories}

This paper is guided by the deprivation theory as propounded by John Bowlby (1969 - 1980). The deprivation theory proposes that every problem that exists is as a direct or indirect result of one form or another of un provided need. It might be lack of physical need, lack of psychological need, lack of spiritual need or a co mbination of depriv ations. This theory that promotes a holistic approach that is human, social, intellectual and spiritual developments of a human person. The theory complements the theory of abundant life since deprivation implies that there is a deficiency of the needs of a human person.Pastoral care is based on deep respect for the dignity and uniqueness of the individual person as all are made in the image of God (Gen .1:27). The relationship between the two theories: abundant life and deprivation. Abundant life theory is a theory of fullness while deprivation is to be denied access to this life. In simple terms absence of abundance life results to deprivation, hence the two theories complement each other.

\section{Method}

\subsection{Target Population and Sample}

The target population included all the principals, heads of departments and students in leadership in the eight secondary schools (Catholic and non-Catholic sponsored) in Nakuru Municipality. The number of respondents was 216 out of 702.

\subsection{Demographic Characteristics}

The researcher sought demographic information of the respondents in order to establish if there was equal representation in the sampling. In this regard, the respondents' background which included the age, academic and professional qualification was sought.

\subsection{Sampling Procedure}

This paper involved a sample size of 216 respondents from Catholic and non-Catholic schools. It comprised of eight principals, 40 heads of departments and 168 students. The students comprised of class prefects, dining hall prefects,' dormitory prefects and five students from each school who have been involved with indiscipline cases. The Catholic schools sampled were four while non-Catholic schools sampled were also four.The study employed purposeful sampling to identify the respondents (Denzin and Lincoln, 2000). I sampled those involved in leadership because they have information at hand by the nature of their responsibilities.

\subsubsection{Sample Size, Power, and Precision}

This paper involved a sample size of 216 respondents from Catholic and non-Catholic schools.The target population included all the principals, heads of departments and students in leadership in the eight secondary schools (Catholic and non-Catholic sponsored) in Nakuru Municipality. The number of respondents was 216 out of 702 .

\subsubsection{Research Instruments}

Data for this paper was collected using three methods namely: questionnaires, unstructured interviews, and focused group discussions.

a) Questionnaires

The questionnaire was one of the main tools for data collection in this paper. The questionnaire had both open and closed ended items. It was divided into two parts. Part one had the bio data and part two had information related to the research problem.

\section{b) Interviews Schedules}

Interview schedules were the other technique used to obtain data from the respondents. Unstructured interviews helped the informant to open up and to produce more information. This method helped to get the required data.

c) Focused Group Discussions

This was the other technique used to obtain data from respondents. This method helps the respondents to discuss freely and give their point of view since one is encouraged to speak. The groups were comprises of ten students.

\subsubsection{Research Design}

This paper employed a case study research design which used qualitative method. The design facilitated a detailed assessment of a single issue which for this study was the challenge of pastoral care in the Catholic Church-sponsored schools in Nakuru Municipality of Nakuru County. Using this design, it was possible to evaluate the unique aspects of the paper in the study area. This paper collected information from respondents on their attitudes and opinions in relation to challenges faced in pastoral care. Data from this paper was collected from school principals, heads of departments and prefects. Both primary and secondary data was used in the study. Primary data was obtained using questionnaires, interviews and focussed group discussions while secondary data 
was obtained from books, journal articles, new spapers, magazines and the internet.

\section{Results}

\subsection{Nature of Pastoral Care}

\subsubsection{Guidance and Counseling}

The guidance and counseling of students is an integral component of the educational mission of the school. Guidance and counseling services and programs promote the spiritual, personal/social, educational and career development of all students. It is at the heart of Pastoral Care. Guidance and counseling has a caring and supportive role in the school where students can get advice and support on a range of issues. Its scope ranges from relationships to study skills and family difficulties to college advice and information. Counseling helps students explore their thoughts and feelings and the various choices open to them in life. It gives care and support to students in the learning process to cope with the many aspects of their lives as they grow up in school life and with their individual personal circu mstances, information for schools, students and families.

\subsubsection{Young Christian Student Movement}

Young Christian Student Movement (YCS) is a movement of the Students, by the Students and for the Students. It is a movement that is solely managed and led by secondary school students. It is an awareness movement that helps young people to analyze their experiences and deepen their awareness of themselves, who they are potentialities, aspirations, and responsibilities how they relate to others (in the family, school and neighborhood etc.), what inspires and conditions them (values and traditions) and how they need to change and can change and grow. This helps them not only use their faith and help put that into practice but to also create the best possible action that will solve the situation around them. Young Christian Student movement is one of the aspects of Pastoral Care which has contributed a lot to character formation in Roman Catholic sponsored schools at Nakuru Municipality evidenced by the reach findings

\subsubsection{Days of Prayer}

Prayer is the medium of communication between God and humanity. It is as a result of th is, that prayer is regarded as a very important tool in character formation of students. From the research findings, there is clear evidence that days of prayer bring about integral formation to learners since it helps them to view life at different perspectives and acquire the courage to face future challenges in life with boldness. This brings about character formation in the life of a student.

\subsubsection{Catechism}

Catechesis is the process of transmitting the Gospel, as the Christian community has received it, understands it, celebrates it, lives it and communicates it. Catechetical formation refers to the entire approach of the congregation "growing in the grace and knowledge of our Lord Jesus Christ." Thus, it includes catechism instruction, family devotions, family and church gatherings that reflect the life of grace and mercy, shaped by proper distinction and application of Law and the Gospel. Catechism is one of the aspects that have enhanced Pastoral Care in Catholic Church sponsored schools. According to the paper's findings, catechism helps in developing one's faith. Socially, it helps in developing the community's faith. Intellectually one understands his or her role as a God's creature. Thus, catechetical formation provides the threads that unite and emphasizes the Christian life and growth.

\subsubsection{Spiritual Talks}

Spiritual formation is a holistic process by which God forms Christ's character in believers by the ministry of the Spirit, in the context of school community, and in accordance with biblical standards. This process involves the transformation of the whole person in thoughts, behaviors, and styles of relating with God and others. It is therefore, an intentional Christian practice that has as its goal the development of spiritual maturity that leads to Christ-likeness. Spiritual formation involves three realms: worship, Bible reading/study and prayer.

The paper observes that spiritual talks play a very important role in the life of students. It brings the transformation of the whole person. Spiritual formation is a holistic process, not me rely about an internal change in the disposition of our hearts, but an internal change that results in the transformation of our whole self-our thoughts, behaviors, and relationships - so that we can increasingly learn how to live the way Jesus lived, love the way Jesus loved and serve the way Jesus served.

\subsubsection{Reciting of the Rosary}

Reciting of the Rosary is a style of mental prayer that is based on repetition. Reciting the rosary is pondering the life of Christ with Mary, as she did in Luke 2:19. The purpose of the Rosary is to help keep in memory certain principal events or mysteries in the history of our salvation, and to thank and praise God for them. Reciting of the Rosary is practiced by most Catholic sponsored schools. This paper points out that the prayer of the rosary involves repetition of Hail Mary's 
and it is an aspect that calls for attention and concentration in what the person is doing.

\subsubsection{Holy Mass}

The Holy Mass is the central act of Catholic worship. The holy Sacrifice of the Mass is celebrated as a memorial of our redemption from the slavery of evil effected by Christ's death on the cross. This view has been explicitly explained by Maslow 1954 where he argues that education with a holistic perspective is concerned with the development of learners since it helps them to grow in all aspects of life: spiritually, physically and emotionally.It seeks to engage students in their teaching or learning process and encourages pers onal and collective responsibility.

This paper observes that holy mass brings about wholesome formation to learners because it enables them to reason critically and creatively. The learners thus became more as sertive in decision making allowing them to bec ome effective participants in solving community problems.

\subsubsection{Pastoral Programme of Instructions}

Pastoral programme of instruction (P.P.I) is a program me that enables students acquire religious nourishment particular to their Christian denomination without emphasis on examination as other subjects in primary school. The findings observed that faith yields abundant fruits as far as holistic formation of the learners is concerned. Pastoral programme of instruction, for instance, stimulates aspects in one's life like self-awareness, self-knowledge, self-understanding and self- acceptance. This is the content that stimulates all faculties in a human person hence holistic formation is experienced.

\subsection{Challenges Facing Pastoral Care in Catholic Church sponsored Secondary Schools}

This paper seeks to report the findings on the challenges facing s mooth running of Pastoral Care in Catholic Church schools in Nakuru Municipality.

\subsubsection{Negative Attitude towards Catholicism}

An attitude is a relatively enduring organization of beliefs around an object or situation predisposing one to respond in some preferential manner. "Attitudes are particularly enduring sets formed by past experiences"(Asch 1952, p. 585). While there may well be a possible hereditary basis for attitudes, as Allport (1950) suggests, all writers agree that attitudes are acquired through the principles of learn ing, whatever these are or may turn out to be. Along with Sherif and Cantril (1945-1946), and Chein (1948), the is sue of what attitudes are, is seen here to be altogether independent of how they are learned.

The paper through the findings observes that negative attitude towards Catholicis $\mathrm{m}$ is like a slow go disease, learners are not true to themselves on what brought them to school and in the process when this negativity crops in, and getting holistic formation is a problem.

\subsubsection{Ignorance}

Ignorance is a state of being uninformed. The word ignorant is an adjective describing a person who is in a state of being unaware of something and is often used to describe individuals who unknowingly or deliberately disregard important information or facts. Pastoral care involves promoting and supporting knowledge of self, self- efficacy, healthy risk taking, goal setting, negotiation, reflection and empowerment to provide optimal learning and develop ment outcomes. It integrates the academic, social and emotional and spiritual dimensions so that an environment of care pervades the entire school community (Access Ministries, 2009). Therefore, if teachers and students are ignorant of the caring partnership between the school community (students, staff, families, and the Christian church) and the wider community, then there is a failure in forming students holistically.

\subsubsection{Different Denominations}

A denomination is an organization of churches that have come together for some common purpose, and who have agreedto be governed by common rules, and who intend to be committed to each other over a long period of time. It is essential for a healthy denomination to share core theological beliefs, a common sense of mission, and mutual accountability. It seems however, that many mainstream denominationshave replaced these essentials Christian values with what is minimal, common history. We are like a family that is bound together by common roots even though we can't live together in harmony because we have so many profound differences and disagreements. When, this is the case in Catholic sponsored schools, then it is a challenge because there is already a division among the denominations and worst enough to relate with the mainstream church. One head of department from a catholic sponsored school in Nakuru Municipalicity went on to report that a student from one of the selected schools exclaimed one time "if there is anything that disturbs me in this school is the Catholic Church that is opposite the school compound." The Church's role in the schools has in some situations been diminished that even in cases of excessive interference by civic authorities, or the commercialization of the education enterprise, imposition of excessive number of subjects and 
text-books, Catholic schools have rarely been able to declare a stand in favor of more pedagogically sound approaches. They have seemed to be at the mercy of government policy no matter the developments, and the public outcries.

\subsubsection{Time Limitation}

This is a time period with in which something must be done or completed. Time limit is a narrow field of time, or a particular point in time, by which an objective or task must be accomplished. Along with other studies made, the researcher decided to explore how to win back students time and improve the quality of school ministries. The research findings from Catholic and non Catholic schools in Nakuru Municipality confirms that time allocated for Pastoral Care programmes is not enough and this leaves so important issues an attended hence students grow up missing some important aspects of their growth in life.

\subsubsection{Peer Influence and Western Influence}

Peer pressure is influence on a noble group, observers or individual exerts that encourages others to change their attitudes, values, or behaviors to conform to groups. Students influence each other not to allow room for this holistic formation. Students have largely adopted the western culture that had a great influence on them. They concentrated so much on what others were doing as it is reported in the media and therefore have no time for their introspection. Students have become copy cats. They engage in drug and substance abuse, prostitution, abortions and all sorts of influence from western culture. There was high competition to be the best but not under what cost. During this time, adolescents are more likely to have low communication skills and high family conflict. Those factors also contribute to substance abuse among adolescents. In addition, if the adolescent becomes involved in illegal drug use, the adolescent is likely to do better in the prevention program if the family is willing to cooperate and be involved in the program as well (Scheer et aI., 20).

\section{Conclusions}

Empirically, this paper established that Pastoral Care programmes have been in co-operated in the school curriculum of Catholic Church-sponsored schools. However, there are a number of challenges facing Pastoral Care. This paper noted that Pastoral Care is given in Catholic Church- sponsored schools but there is no systematic approach to this. There is no approved curriculu m which leaves out other as pects omitted hence disconnect. Since there is no approved curriculu m, it follows that no examination is administered and therefore neither the teachers nor the students are committed to the teaching of Pastoral Care. Moreover, in these Catholic Church-sponsored schools, three quarters of students are from other denominations. Along with other aspects, Pastoral Care entails teaching the Catholic doctrine of faith, as such, students from other denominations are disinterested and are only attracted to academic performance but not anything else out of that scope.

Theoretically, the above challenges can be attributed to no access to abundant life which is as a result of deprivation.This agrees with the theory of abundant life and deprivation which guided this paper that whenever there is deprivation, there is no fullness in life. It is clear from the study that the challenge to Pastoral Care continues to persist, without any solutions on site. But the persisting aspects give solutions.

\section{Acknowledgements}

I am grateful to God who has enabled me to write this paper. I thank my supervisors Dr. B.K. Onyancha, and Dr. J. O. Ayiemba whose constant invaluable, positive criticism, patience, time and moral support at every stage of this paper facilitated its completion. Special thanks goes to the congregation of the Religious of the Incarnate Word who have moulded me in human, psychological, intellectual and spiritual dimensions to be the person whom I am today.

I am particularly grateful to the Rt. Rev. Bishop Phillip Anyolo for recommending me for scholarship with Kir Not. I cannot forget the encouragement and support I received from Prof. M.M Theuri and the late Mr Peter Kudoyi who enabled me to cope up with the situation of the loss of my dearest mother at the beginning of my master's degree programme which has to be crowned by presenting this paper before graduation.

I sincerely wish to express my gratitude to Mr.Kizito Odock and to all those who assisted me in one way or another with much dedication, by taking their time in helping me proof read the work and by giving me more encouragement. I would also like to thank all the respondents who provided me with the valuable information that informed this paper. In particular, I would like to recognize the principal, teaching staff and students of Christ the King Academy for their patience while I was away from school for my studies. To the teaching staff and students in different schools selected for data collection, I say thank you all. 


\section{References}

Access Ministries. (2009). We Are There: The Value of Chaplains in Victorian Schools, Melbourne, Access Ministries. Adams, J. (1970). Competent to Counsel, Grand Rapids: Baker Book House.

Augsburger, D. W. (1995). Pastoral Counseling Across Cultures, West Minister, John Knox Press.

Benner, G. D. (2003). Strategic Pastoral Counseling, Baker Academic Publishing group.

Berg, L. S. (1989). Alcoholismand Pastoral Ministry-Readings on Recovery, Michigan Guest House, Inc. Lake Orion.

Bonnie, M. M., \& Christie, C. N. (2004) Pastoral Care and Counselling Redefining the Paradig ms, New York, Abingdon Press.

Card inal Archbishop of West minister. (1983). The Code of Canon Law, London, Collins Liturgical Publication 187 Piccadilly.

Clinebell, H. (1984). Basic Types of Pastoral Care and Counseling, Nashville, Abingdon Press.

Damary, R. (2012). The Star(Nairobi).

David, B. B. et al. (1973). Kenya Churches Hardbook: The Development of Kenyan Christianity, 1498 - 1973, Nairobi, Evangel Publishing House.

David, K. S. (2000). Pastoral Care Emergence, Creative Pastoral Care and Counselling, London, Abingdon Press.

Dayringe, R. (1998). The Heart of Pastoral Counseling,Haworth,Kansas, Pastoral press.

Deborah, V. D. H. (1995). Theology and Pastoral Counseling - A New Interdisciplinary Approach, Wm. B. New York, Eerdmans Publishing Amazon.com.

Dennis, L. (2006). Spirituality in Counselling and Psychotherapy, New York, Abingdon Press.

Denzin, N. K., \& Lincoln, Y. S. (2000). Handbook of Qualitative Research, Sage, 2nd edn. Thousand Oaks.

Dittes, E. J. (1999). Pastoral Counselling, the Basics, West Minister, John Knox Press.Doehring, Carrie, The Practice of Pastoral Care, West Minister, John Knox Press.

Edward, P. W. (2004).Using Scripture in Pastoral Counseling,London,Abingdon Press.

Emmanuel, Y. L., \& Newton, P. J. (2003). In Living Color, An Intercultural Approach to Pastoral Care and Counselling, London, Abingdon Press.

Floyd, S. (2008). Crisis Counseling: A Guide for Pastors and Professionals, NewYork,Kregel Academic .

Flynn, M., \& Mok, M. (2002). Catholic Schools 2000.A Longitudinal Study of Year, 12 Students in Catholic Schools.CEC, New South Wales.

Gerkin, V. C. (1994). An Introduction to Pastoral Care, West Minister, Abingdon Press.

Gillian Rosemary Evans. (1983). A History of Pastoral Care, London, Continuum International Publishing Group.

Gordon, L. (2002). Pastoral Care and Counselling Ethics in Practice Series, New York, Sage publishers.Gorsuch Nancy, J. (1999). Pastoral Visitation, Creative Pastoral Care and Counseling, New York, Fortress Press.

Gros soehme, D. H. (1999). The Pastoral Care of Children, London, Abingdon Press.

Gubi, M. P. (2007). Prayer in Counseling and Psychotherapy, Exploring a Hidden Meaningful Dimension, Kingsley, Jessica Kingsley Publishers.

Hiltner, S. (1954). Preface to Pastoral Theology, New York, Abingdon Press.

Howard, J. C. (1984). Basic Types of Pastoral Care and Counselling, Resources for the min istry of Healing and Growth, London, Abingdon Press.

Janse, \& Rensburg, J. (2009). Poverty and Pastoral Counselling: South Africa, Design for An Extensive Research Project', Verbum et Ecclesia, 30(20).

Johan, J. V. R. (2010). A Holistic Approach to Pastoral Care and Poverty, New York, Open journals publishing.

Kenneth, C. H., \& Barry, A. H. (1975). Pastoral Care and Counselling, A Survery of Recommended Readings, New York, Abingdon Press.

Kenyatta. (1965). The Colombia guide to East African literature in English, New York, Colombia University press.

Lebacqz, K., \& Driskill, D. J. (1945). Ethics and Spiritual Care, New York, Abingdon Press. 
Lester, D. A. (1995). Hope in Pastoral Care and Counseling, West Minister, John Knox Press.

Makumba, M. M. (2012). The Role of Catholic Church in Education in Kenya, a letter written by commission for Education and Religious Education, Kenya Catholic Secretariat.

Muhoho, G. K. (1970). The Church's Role in the Development of Educational Policy in the Pluralistic Society in Kenya.PhD. Pontifical Universitas Urbaniana.

Nadge, A. (2005). Academic care: building resilience, building futures. Obiria, Moraa $11^{\text {th }}$ May 2012, The Star (Nairobi)

Pattison, S. (1993). A Critique of Pastoral Care, New York, Abingdon press.

Patton, J. (2005). Pastoral Care, An Essential Guide, New York, Abingdon press.

Ramsay, N. J. (1998). Pastoral Diagonosis, New York, Self-Publishing Account.

Ronald, W. R. (1999). Creating a Healthier Church,:Family Systems Theory, Leadership and Congregational Life. Creative Pastoral Care and Counseling series.

Scheer, S. D., Borden, L. M., \& Donnermeyer, F. (2000). The relationship between family factors and adolescent substance use in rural, suburban, and urban settings.Journal of Child and Family Studies, 9(1), 105-115. Retrieved October 12, 2005 from the EBSCOhost database.

Second Vatican Council. Declaration on Christian Education, GravissimumEducationis.

Second Vatican Council. Pastoral Constitution on the Church in the Modern World "Gaudiumet Spes",

Smith, C. (2003a). Religious participation and network closure among American adolescents.Journal for the Scientific Study of Religion, 42(2), 259-267. Retrieved September 28, 2005 from the EBSCOhost database.

Smith, C. (2003b). Theorizing religious effects among American adolescents. Journal for the Scientific Study of Religion, 42(1), 17-30. Retrieved September 28, 2005 from the EBSCOhost database.

Steven L. B. (1989). Alcoholism and Pastoral Ministry: Readings on Recovery, Lake Orion, Michigan Guest House, Inc.

Stone, W. H. (1993). Crisis Counselling, New York, Fortress Press.

Vision Statement for Catholic Schools, Sydney Archdiocesan Catholic Schools Board (new edition), March, 2002.

Ward. A. K., \& Harold, G. K. (2002). Pastoral Counseling, London, AGesalt Approach-Routledge.

Waters, J. (2011). Readings in Pastoral Care and counseling an E Book for Sanctus Theological Institute the Christicministry, New York, Progressive Catholic Review.

\section{(cc) $\mathrm{BY}$}

This work is licensed under a Creative Commons Attribution 3.0 License. 